\title{
Dietary agent, benzyl isothiocyanate inhibits signal transducer and activator of transcription 3 phosphorylation and collaborates with sulforaphane in the growth suppression of PANC-I cancer cells Brian Hutzen ${ }^{1,2}$, William Willis ${ }^{3}$, Sarah Jones ${ }^{1}$, Ling Cen ${ }^{1}$, Stephanie Deangelis ${ }^{1}$, Beng Fuh ${ }^{4}$ and Jiayuh Lin*1,2,3,5
}

Address: ${ }^{1}$ Department of Pediatrics, The Research Institute at Nationwide Childrens' Hospital, Columbus, OH, USA, ${ }^{2}$ Molecular, Cellular, and Developmental Biology Program, The Ohio State University, Columbus, OH, USA, ${ }^{3}$ Integrated Biomedical Science Graduate Program, The Ohio State University, Columbus, OH, USA, ${ }^{4}$ Department of Pediatrics, BSOM, East Carolina University, Greenville, NC, USA and ${ }^{5}$ Experimental Therapeutics Program, The Ohio State University Comprehensive Cancer Center, College of Medicine, The Ohio State University, Columbus Ohio, USA

Email: Brian Hutzen - Hutzen.1@osu.edu; William Willis - wllmwillis45@aol.com; Sarah Jones - jones.2328@osu.edu; Ling Cen - Cen.Ling@mayo.edu; Stephanie Deangelis - deangelis.13@osu.edu; Beng Fuh - FUHB@ecu.edu; Jiayuh Lin* - lin.674@osu.edu

* Corresponding author

Published: 27 August 2009

Cancer Cell International 2009, 9:24 doi:10.I 186//475-2867-9-24

This article is available from: http://www.cancerci.com/content/9/I/2

(C) 2009 Hutzen et al; licensee BioMed Central Ltd.

This is an Open Access article distributed under the terms of the Creative Commons Attribution License (http://creativecommons.org/licenses/by/2.0), which permits unrestricted use, distribution, and reproduction in any medium, provided the original work is properly cited.
Received: 17 September 2008

Accepted: 27 August 2009

\begin{abstract}
The Signal Transducer and Activator of Transcription (STAT) proteins comprise a family of latent transcription factors with diverse functions. STAT3 has well established roles in cell proliferation, growth and survival, and its persistent activation has been detected with high frequency in many human cancers. As constitutive activation of STAT3 appears to be vital for the continued survival of these cancerous cells, it has emerged as an attractive target for chemotherapeutics. We examined whether the inhibitory activities of bioactive compounds from cruciferous vegetables, such as Benzyl isothiocyanate (BITC) and sulforaphane, extended to STAT3 activation in PANC-I human pancreatic cancer cells. BITC and sulforaphane were both capable of inhibiting cell viability and inducing apoptosis in PANC-I. Sulforaphane had minimal effect on the direct inhibition of STAT3 tyrosine phosphorylation, however, suggesting its inhibitory activities are most likely STAT3-independent. Conversely, BITC was shown to inhibit the tyrosine phosphorylation of STAT3, but not the phosphorylation of ERK I/2, MAPK and p70S6 kinase. These results suggest that STAT3 may be one of the targets of BITC-mediated inhibition of cell viability in PANC-I cancer cells. In addition, we show that BITC can prevent the induction of STAT3 activation by Interleukin6 in MDA-MB-453 breast cancer cells. Furthermore, combinations of BITC and sulforaphane inhibited cell viability and STAT3 phosphorylation more dramatically than either agent alone. These findings suggest that the combination of the dietary agents BITC and sulforaphane has potent inhibitory activity in pancreatic cancer cells and that they may have translational potential as chemopreventative or therapeutic agents.
\end{abstract}




\section{Background}

Despite major advances in the detection and treatment of cancer in the past few decades, cancers of the pancreas are still rarely curable; the five-year survival rate of pancreatic cancer patients remains less than 5\% [1]. Pancreatic cancers generally respond poorly to conventional treatment modalities such as chemotherapy and radiation therapy, necessitating the discovery and development of more effective means for their treatment [2].

The etiology of pancreatic cancer is poorly understood, but it involves the multi-stage development of aberrations in signaling pathways that affect cell growth and proliferation [3]. Recent studies have revealed the identities of several of these signaling proteins, including those associated with the ERK, AKT, mTOR and STAT3 pathways [4]. STAT3 is a member of the STAT family of transcription factors, which is transiently activated in response to cytokine and growth factor receptor stimulation [5-8]. Although it plays necessary roles in early development, the presence of STAT3 in the majority of adult tissue and cell types is mostly dispensable [9-11]. Constitutive STAT3 signaling has been implicated as a contributor to oncogenesis for its roles in stimulating cell proliferation, mediating immune evasion, promoting angiogenesis, and conferring resistance to apoptosis as induced by conventional therapies [12-16]. Persistent activation of STAT3 is frequently detected in a wide range of blood and solid tumors, including those of the pancreas [17-20]. Consequently, the inhibition of STAT3 by a variety of means has been demonstrated to exert a potent anti-cancer effect $[15,21,22]$.

In the present study, we investigated the potential inhibitory effects of BITC and sulforaphane on persistent STAT3 activation in the PANC-1 pancreatic carcinoma cell line. BITC and sulforaphane are cruciferous vegetable-derived compounds which have been shown to inhibit chemically induced cancer in various animal models [23-28]. BITC is known to up-regulate the cyclin dependent kinase (Cdk) inhibitor p21Waf1/Cip1[29], induce a marked decline of Cdk1, cyclin B1 and cell division cycle 25B, and inhibit activation of nuclear factor $\kappa \mathrm{B}(\mathrm{NF}-\kappa \mathrm{B})$ [30]. Sulforaphane has also been shown to inhibit NF- $\kappa B$ [31], histone deacetylase activity [32], and AKT phosphorylation [33], and it possesses several other anti-cancer activities [34]. It is presently unclear whether BITC or sulforaphane have any inhibitory effect on STAT3 activation in pancreatic cancers.

\section{Results \\ Sulforaphane and BITC inhibit cell viability and induce apoptosis in PANC-I pancreatic cancer cells}

We first examined the effect of sulforaphane and BITC treatment on the viability of PANC-1 as determined by MTT assays. At day 3 post-treatment, 5, 10, and $20 \mu \mathrm{M}$ concentrations of sulforaphane inhibited approximately $30 \%, 50 \%$, and $65 \%$ of cell viability respectively (Figure 1A). At day 5 post-treatment, $5 \mu \mathrm{M}$ of sulforaphane was found to inhibit approximately $65 \%$ of cell viability; concentrations of $10 \mu \mathrm{M}$ and $20 \mu \mathrm{M}$ reduced viability below detectable levels (Figure 1A). We then investigated the effect of sulforaphane treatment on the phosphorylation status of STAT3. The activation of STAT3 is contingent upon phosphorylation of tyrosine residue 705 (Y705), an event typically preceded by the interaction of specific cytokines and growth factors with their cognate receptors $[7,8]$. Western blots were performed using lysates from PANC-1 cells treated with various concentrations of sulforaphane for 24 hours and a Y705-specific STAT3 antibody. Sulforaphane concentrations as high as $20 \mu \mathrm{M}$ had no discernable effect on levels of phosphorylated STAT3 (pSTAT3) and minimal inhibitory activity on phosphorylated ERK 1/2, two closely related MAP kinases that are also regulated in part by tyrosine phosphorylation (Figure 1B) [35]. Concentrations of 10 and $20 \mu \mathrm{M}$ sulforaphane were capable of inducing apoptosis in PANC-1 however, as evidenced by increased cleavage of poly-(ADP-ribose) polymerase (PARP), an early target of active caspases and a marker for apoptosis (Figure 1B) [36]. Taken together, these observations suggest that sulforaphane's inhibitory activities against PANC-1 are achieved by means independent of STAT3.

Similar experiments were performed with BITC concentrations ranging from 5 to $30 \mu \mathrm{M}$. The addition of BITC to the media likewise resulted in dose-dependent inhibition of the PANC-1 cells' viability, albeit to a comparatively lesser extent than that exhibited by sulforaphane (Figure 1C). In contrast to sulforaphane, Western blot analysis of cell lysates from BITC-treated samples revealed that levels of pSTAT3 dropped sharply at $20 \mu \mathrm{M}$ BITC and were virtually undetectable at $30 \mu \mathrm{M}$ (Figure 1D). Levels of phosphorylated ERK 1/2, however, remained relatively consistent. BITC was also found to induce apoptosis as determined by PARP cleavage (Figure 1D). These results suggest that BITC-mediated inhibition of PANC-1 may be at least partially dependent on suppression of activated STAT3.

\section{BITC treatment inhibits transcription of STAT3 target genes}

To confirm our observations, we next performed nonquantitative reverse transcriptase PCR (RT-PCR) with cDNA generated from sulforaphane- and BITC-treated PANC-1 cells. We limited our investigation to well-characterized STAT3 target genes, such as the cell cycle regulator Cyclin D1, the anti-apoptotic proteins Survivin and Bcl$\mathrm{Xl}$, and the angiogenic mediator, vascular endothelial growth factor (VEGF) [37,38]. Sulforaphane treatments as high as $50 \mu \mathrm{M}$ had marginal impact on the expression of these genes, whereas equimolar concentrations of BITC 
A.

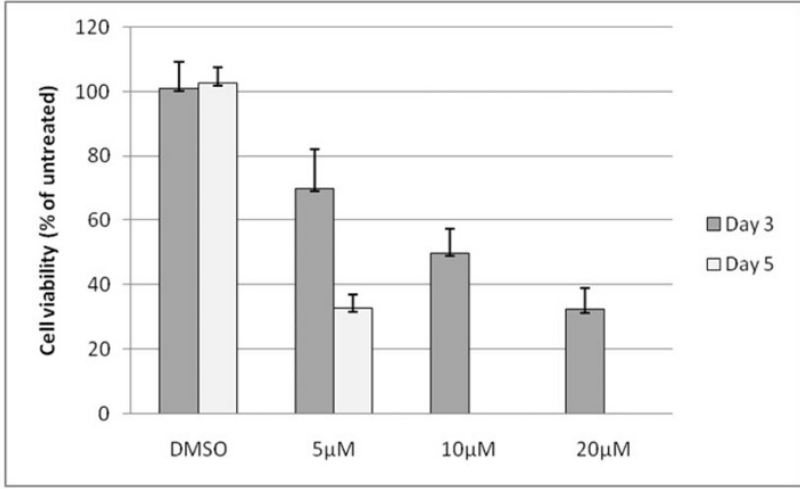

C.

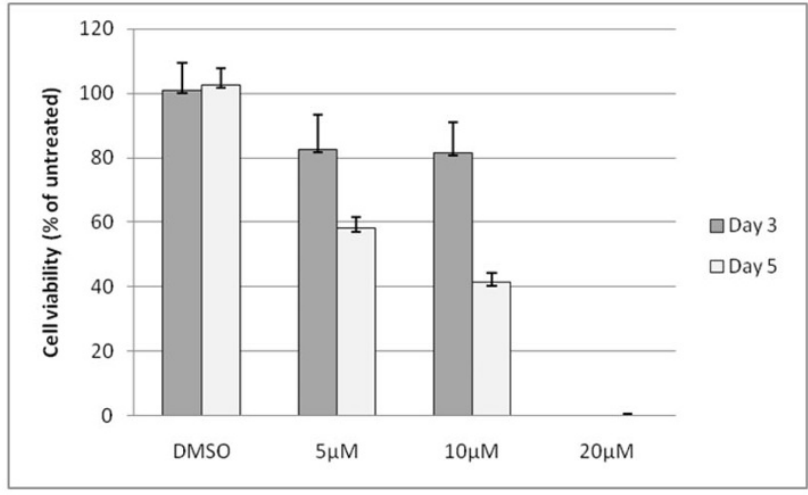

B.

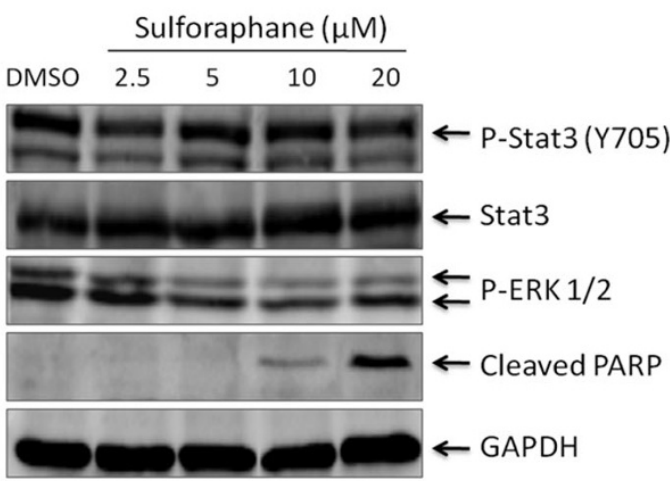

D.

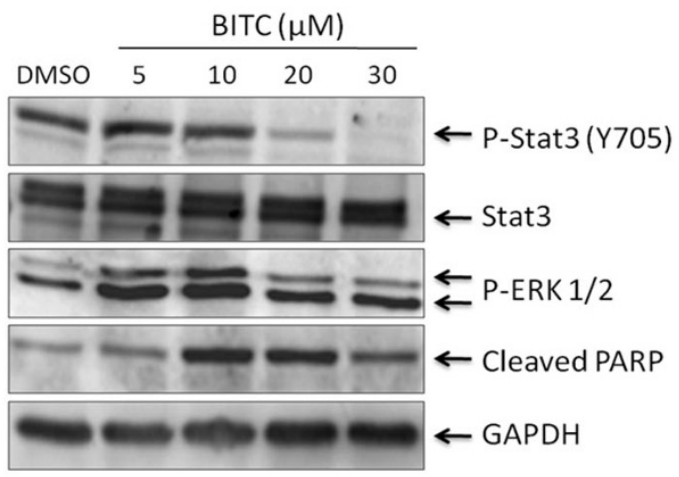

Figure I

The viability of PANC-I pancreatic cancer cells is negatively impacted by sulforaphane and BITC. (A) PANC-I cells were treated with 5,10 , and $20 \mu \mathrm{M}$ of sulforaphane for 3 and 5 days, after which MTT assays were used to assess cell viability. (B) Treatment of PANC-I with $2.520 \mu \mathrm{M}$ sulforaphane results in a marked increase in cleaved PARP, but otherwise has little to no impact on levels of phospho-ERKI/2 and PSTAT3. (C) Treatment of PANC-I with 5, 10 and $20 \mu M$ BITC lowers PANC-I viability to a lesser extent than that exhibited by sulforaphane. (D) BITC reduces levels of pSTAT3 in a dose-dependent fashion and increases levels of PARP cleavage, but has minimal effect on levels of phospho-ERKI/2.

\begin{tabular}{|c|c|c|c|c|c|c|c|}
\hline \multirow[b]{2}{*}{ NT } & \multicolumn{3}{|c|}{ Sulforaphane $(\mu \mathrm{M})$} & \multicolumn{2}{|c|}{$\mathrm{BITC}(\mu \mathrm{M})$} & \multirow[b]{2}{*}{ Neg. } & \\
\hline & 10 & 20 & 50 & 20 & 50 & & \\
\hline 60 & 20 & 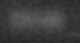 & & con & & & Cyclin D1 \\
\hline c & 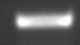 & 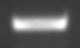 & a & $\mathrm{cos}$ & & & Survivin \\
\hline$-\infty$ & $=$ & $=$ & 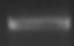 & $=$ & & & $\mathrm{Bcl}-\mathrm{XI}$ \\
\hline 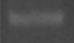 & $=$ & $\ln x$ & -6 & $\cos x$ & & & VEGF \\
\hline 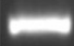 & 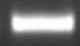 & & & Cons & 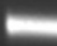 & & GAPDH \\
\hline
\end{tabular}

\section{Figure 2}

BITC impacts expression of STAT3 target genes.

Non-quantitative RT-PCR shows BITC, but not sulforaphane, reduces transcription of several STAT3 target genes after 24 hours of treatment. NT = untreated. Neg. = no cDNA negative control. resulted in their suppression (Figure 2). These results again suggest that BITC-mediated inhibition of PANC-1 occurs through STAT3-dependent processes.

\section{BITC prevents phosphorylation of STAT3 by IL-6}

Interleukin-6 (IL-6), a pleiotropic and proinflammatory cytokine, is known to be a potent activator of STAT3 [8]. Elevated serum levels of IL- 6 are often associated with the pathogenesis of many cancers, including those of the pancreas and breast $[39,40]$. Following the observation that BITC could inhibit the phosphorylation of STAT3, we investigated if this compound was also capable of preventing STAT3 activation as mediated by IL-6. The already high endogenous levels of pSTAT3 in PANC-1 necessitated use of another cell line for these experiments. MDAMB-453, a breast carcinoma cell line, was chosen due to its lack of detectable pSTAT3 in the absence of specific external factors. The addition of $50 \mathrm{ng} / \mathrm{ml}$ of IL- 6 to the media of the MDA-MB-453 cells leads to rapid induction 
of pSTAT3, with maximum phosphorylation levels peaking within approximately 30 minutes (data not shown). When we pre-treated MDA-MB-453 cells with $50 \mu \mathrm{M}$ concentrations of sulforaphane or BITC for two hours prior to the addition of $50 \mathrm{ng} / \mathrm{ml}$ IL- 6 exposure, phosporylation of STAT3 was almost completely nullified by BITC (Figure 3 ). The molecular underpinnings for this inhibition remain to be elucidated, but given the short timeframe in which BITC is able to inhibit IL-6 mediated pSTAT3, BITC might be expected to somehow interfere with proper assembly or functioning of the IL- 6 receptor complex, or perhaps disrupt the subsequent interaction of an IL-6dependent kinase with STAT3. There is also the possibility that BITC directly interfaces with STAT3 itself. These hypotheses await further experimentation.

\section{The combination of sulforaphane and BITC is more potent than either agent alone}

Finally, we investigated whether BITC and sulforaphane had synergistic qualities. We again performed MTT viability assays using $10 \mu \mathrm{M}$ concentrations of sulforaphane and BITC, both alone and in conjunction. Following three days of treatment, $10 \mu \mathrm{M}$ concentrations of BITC or sulforaphane reduced viability in PANC-1 cells by approximately $20 \%$ and $50 \%$ respectively (Figure 4 A). PANC- 1 cells treated with $10 \mu \mathrm{M}$ BITC and $10 \mu \mathrm{M}$ sulforaphane in conjunction displayed a greater than $80 \%$ reduction in viability (Figure 4A). This observation correlated with decreased levels of pSTAT3 and an increase in PARP cleavage as determined by Western blot (Figure 4B), as well as drastic alterations in morphology and overall cell number (Figure 4C).

\section{Discussion}

Each year, approximately 40,000 individuals in the United States are diagnosed with pancreatic cancer [1]. Despite advancements in detection and treatment, the majority of these pancreatic cancer cases carry a grim prog-

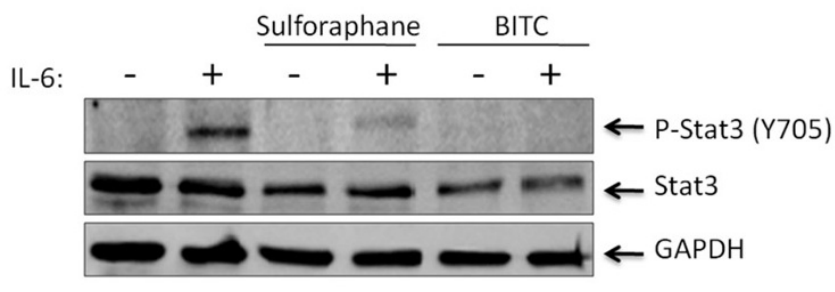

Figure 3

Sulforpahane and BITC inhibit phosphorylation of STAT3 by IL-6. The addition of $50 \mathrm{ng} / \mathrm{ml}$ of interleukin-6 stimulates STAT3 phosphorylation in MDA-MB-453 breast cancer cells. Pre-treatment of these cells with $50 \mu \mathrm{M}$ sulforaphane or BITC resulted in the reduction or complete abrogation of PSTAT3 respectively. nosis. Even when detected early, cancer of the exocrine pancreas is rarely curable and has an overall survival rate of less than $4 \%$. For patients with localized disease and small cancers $(<2 \mathrm{~cm})$ with no lymph node metastases and no extension beyond the capsule of the pancreas, complete surgical resection can yield actuarial 5-year survival rates of only $18 \%$ to $24 \%$ [41]. For those patients with advanced cancers, the 5-year survival rate of all stages plummets to less than $1 \%$, reflective of the poor response to chemotherapy and radiation therapy as conventionally used $[2,42,43]$. There is thus an urgent need to identify and develop more effective treatments for pancreatic cancer.

We identified a novel function of BITC to inhibit the tyrosine phosphorylation of STAT3 and prevent its induction by IL-6. BITC and sulforaphane were both capable of inhibiting cell viability and inducing apoptosis in PANC1. Sulforaphane had minimal effect on the direct inhibition of STAT3 tyrosine phosphorylation, however, suggesting its inhibitory activities are most likely STAT3independent. Conversely, BITC was shown to inhibit the tyrosine phosphorylation of STAT3, but not the phosphorylation of ERK1/2. These results suggest that STAT3 may be one of the targets of BITC-mediated inhibition of cell viability in PANC-1 cancer cells. Our results also suggest that the combination of bioactive compounds such as BITC and sulforaphane from cruciferous vegetables have potent inhibitory activity in human pancreatic cancer cells and may have potential as preventative or therapeutic agents.

\section{Materials and methods Cell Culture}

PANC-1 pancreatic cancer cells and MDA-MB-453 breast cancer cells were acquired from ATCC. These cells were maintained in $1 \times$ Dulbecco's Modified Eagle's Medium (DMEM) supplemented with $10 \%$ fetal bovine serum (FBS) (Invitrogen), $4.5 \mathrm{~g} / \mathrm{L}$, L-glutamine, \& sodium pyruvate (Mediatech) and $1 \%$ Penicillin/Streptomycin in cell culture incubators set at $37^{\circ} \mathrm{C}$ and $5 \% \mathrm{CO}_{2}$.

\section{Western blot analysis}

PANC-1 cells were treated with sulforaphane or BITC (Sigma-Aldrich) for 24 hours. In combination experiments, PANC-1 cells were treated with $10 \mu \mathrm{M}$ of sulforaphane and/or $10 \mu \mathrm{M}$ of BITC for 24 hours. For IL- 6 experiments, MDA-MB-453 cells were pre-incubated with $50 \mu \mathrm{M}$ sulforaphane or BITC for 2 hours before addition of $50 \mathrm{ng} / \mathrm{ml}$ IL-6 (Cell Sciences, Canton, MA). Western blots were conducted following SDS-PAGE of $100 \mu \mathrm{g}$ of total lysate per sample. Membranes were blotted with antibodies specific for pSTAT3 Y705, STAT3, phosphoERK1/2, cleaved PARP (Cell Signaling Tech) and GAPDH (Chemicon International Inc.). Membranes were ana- 
A.

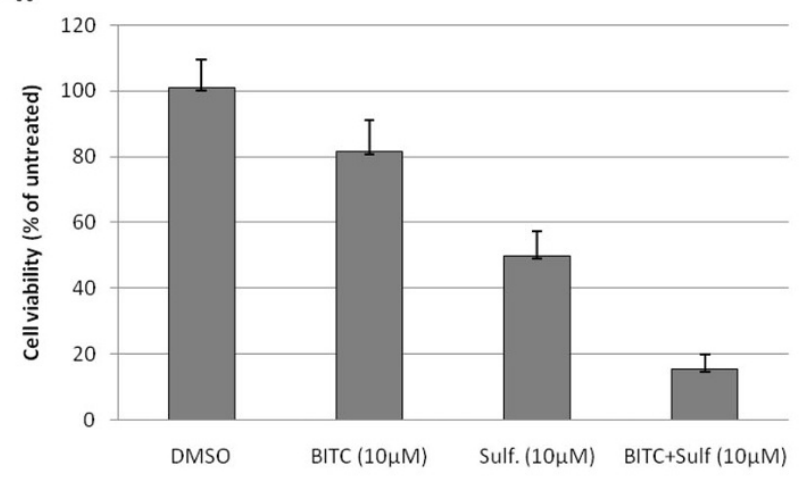

C.

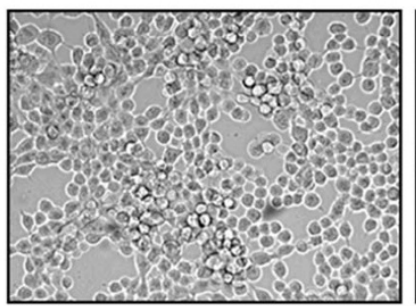

DMSO

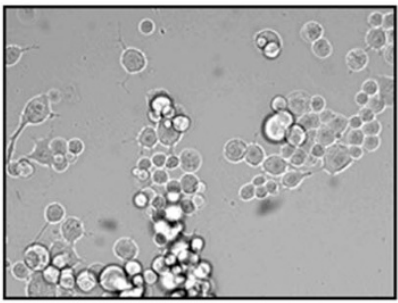

$10 \mu \mathrm{M}$ BITC

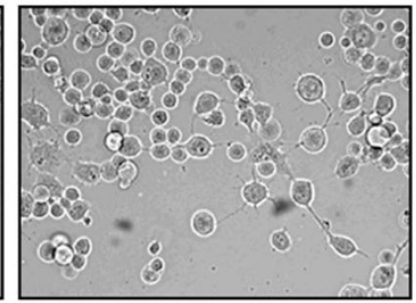

$10 \mu \mathrm{M}$ Sulforaphane
B. DMSO:

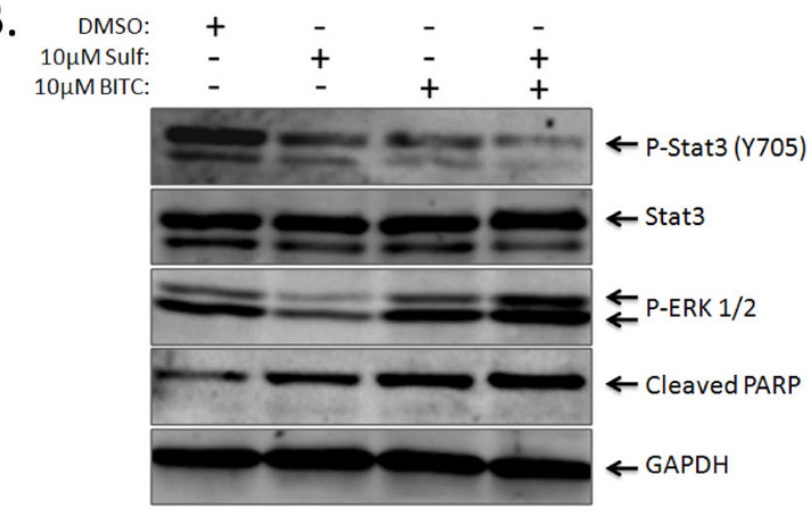

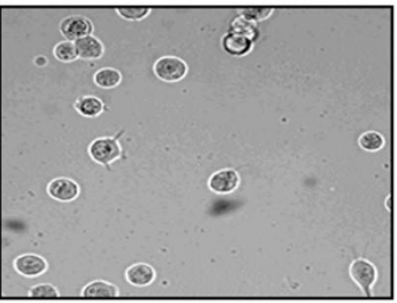

$10 \mu \mathrm{M} \mathrm{BITC}+$ $10 \mu \mathrm{M}$ Sulforaphane

\section{Figure 4}

The combination of sulforaphane and BITC inhibit cell viability to a greater extent than either agent acting separately. (B) Western blot analysis of PANC-I samples 24 hours post-treatment with the listed agents. (C) Sulforaphane and BITC alter the morphology and density of PANC-I cells. Photographs were taken four days after treatment.

lyzed with enhanced chemiluminescence Plus reagents and scanned with a Storm phosphorimager (Amersham Pharmacia Biotech Inc.).

\section{MTT Cell Viability Assay}

PANC-1 cells were seeded in 96-well plates (6000 cells/ well) in 10\% FBS DMEM. After 24 hours, the media was replaced with 5\% FBS DMEM and $0,5,10$, and $20 \mu \mathrm{M}$ sulforaphane or BITC for 3 or 5 days. In separate experiments, $10 \mu \mathrm{M}$ of sulforaphane and BITC, either alone or in combination was added to PANC-1 cells for 3 days. At the end of each time point, $25 \mu \mathrm{l}$ of MTT (Thiazolyl Blue Tetrazolium Bromide) was added to each well of the plate and incubated for 3.5 hours. Afterwards, $100 \mu \mathrm{l}$ of N, Ndimethylformamide (Sigma-Aldrich) solubilization solution was added to each well. Plates were left at room temperature overnight to allow complete cell lysis, and read at $450 \mathrm{~nm}$ the following day. All experiments were repeated three times. Results are presented as averages with error bars representing one standard deviation.

\section{Reverse-transcriptase PCR}

RNA was collected from PANC-1 cells with RNeasy Kits (Qiagen) following 24 hours of treatment with sulforaphane or BITC. cDNA was generated from 500 ng sample RNA using Omniscript RT (Qiagen). Two $\mu$ l of cDNA was subsequently used for PCR. PCR amplifications were performed as follows: $5 \mathrm{~min}$ at $94^{\circ} \mathrm{C}$ followed by 25 cycles of [30 sec at $94^{\circ} \mathrm{C}, 30 \mathrm{sec}$ at $55^{\circ} \mathrm{C}, 30 \mathrm{sec}$ at $72^{\circ} \mathrm{C}$ ] and a final extension at $72^{\circ} \mathrm{C}$ for $5 \mathrm{~min}$. The PCR products were then run on $2 \%$ agarose gels, stained with ethidium bromide and visualized under UV light. Primer sequences and source information are available on request.

\section{Bright Field Microscopy}

$4 \times 10^{4}$ PANC- 1 cells/well were seeded in six-well plates in $10 \%$ FBS DMEM and treated 24 hours later with sulforaphane and/or BITC. After four days of incubation, the cells were washed with PBS before being photographed under bright field microscopy at $100 \times$ magnification. Images were taken with a Model 9.0 Monochrome- 6 camera on a computer equipped with Spot Advanced imaging software 
(Diagnostic Instruments Inc., Sterling Heights, MI). Three images of each treatment were taken from randomly chosen fields, and a representative image was selected for display in the figure.

\section{Competing interests}

The authors declare that they have no competing interests.

\section{Authors' contributions}

BH and WW carried out experiments for Western blotting and data analysis. SJ, SD, and BF carried out experiments for cell viability using MTT assays. LC, BH and JL contributed to the writing of the manuscript and participated in experimental designs. All authors read and approved the final manuscript.

\section{Acknowledgements}

This work was supported in part by the National Foundation for Cancer Research and Susan G. Komen Breast Cancer Foundation grants to Jiayuh Lin.

\section{References}

I. Jemal A, Siegel R, Ward E, Hao Y, Xu J, Murray T, Thun MJ: Cancer statistics, 2008. CA: a cancer journal for clinicians 2008, 58(2):7I-96.

2. Kelsen D: The use of chemotherapy in the treatment of advanced gastric and pancreas cancer. Seminars in oncology I994, 2 I (4 Suppl 7):58-66.

3. Hornberg JJ, Bruggeman FJ, Westerhoff HV, Lankelma J: Cancer: a Systems Biology disease. Bio Systems 2006, 83(23):8I-90.

4. Pham NA, Schwock J, lakovlev V, Pond G, Hedley DW, Tsao MS Immunohistochemical analysis of changes in signaling pathway activation downstream of growth factor receptors in pancreatic duct cell carcinogenesis. BMC cancer 2008, 8:43.

5. Copeland NG, Gilbert DJ, Schindler C, Zhong Z, Wen Z, Darnell JE Jr, Mui AL, Miyajima A, Quelle FW, Ihle JN, et al.: Distribution of the mammalian Stat gene family in mouse chromosomes. Genomics 1995, 29(I):225-228.

6. Ihle JN: The Stat family in cytokine signaling. Current opinion in cell biology 200I, I3(2):21 I-2I7.

7. Darnell JE Jr, Kerr IM, Stark GR: Jak-STAT pathways and transcriptional activation in response to IFNs and other extracellular signaling proteins. Science (New York, NY) 1994, 264(5 1 64): |4|5-|42|.

8. Zhong Z, Wen Z, Darnell JE Jr: Stat3: a STAT family member activated by tyrosine phosphorylation in response to epidermal growth factor and interleukin-6. Science (New York, NY) 1994, 264(5 I 55):95-98

9. Takeda K, Noguchi K, Shi W, Tanaka T, Matsumoto M, Yoshida N, Kishimoto T, Akira S: Targeted disruption of the mouse Stat3 gene leads to early embryonic lethality. Proceedings of the National Academy of Sciences of the United States of America 1997, 94(8):380I-3804.

10. Akira S: Roles of STAT3 defined by tissue-specific gene targeting. Oncogene 2000, I9(2I):2607-26II.

II. Aggarwal BB, Sethi G, Ahn KS, Sandur SK, Pandey MK, Kunnumakkara $A B$, Sung $B$, Ichikawa $H$ : Targeting signal-transducer-and-activator-of-transcription-3 for prevention and therapy of cancer: modern target but ancient solution. Annals of the New York Academy of Sciences 2006, I091:151-169.

12. Real PJ, Sierra A, De Juan A, Segovia JC, Lopez-Vega JM, FernandezLuna JL: Resistance to chemotherapy via Stat3-dependent overexpression of $\mathrm{Bcl}-2$ in metastatic breast cancer cells. Oncogene 2002, 2 I(50):76 | I-7618.

13. Shen Y, Devgan G, Darnell JE Jr, Bromberg JF: Constitutively activated Stat3 protects fibroblasts from serum withdrawal and UV-induced apoptosis and antagonizes the proapoptotic effects of activated Stat I. Proceedings of the National Academy of Sciences of the United States of America 200I, 98(4): I543-I548.
14. Wang T, Niu G, Kortylewski M, Burdelya L, Shain K, Zhang S, Bhattacharya R, Gabrilovich D, Heller R, Coppola D, et al.: Regulation of the innate and adaptive immune responses by Stat-3 signaling in tumor cells. Nature medicine 2004, I O(I):48-54.

15. Buettner R, Mora LB, Jove R: Activated STAT signaling in human tumors provides novel molecular targets for therapeutic intervention. Clin Cancer Res 2002, 8(4):945-954.

16. Alas S, Bonavida B: Inhibition of constitutive STAT3 activity sensitizes resistant non-Hodgkin's lymphoma and multiple myeloma to chemotherapeutic drug-mediated apoptosis. Clin Cancer Res 2003, 9(I):3 16-326.

17. Scholz A, Heinze S, Detjen KM, Peters M, Welzel M, Hauff P, Schirner $M$, Wiedenmann B, Rosewicz S: Activated signal transducer and activator of transcription 3 (STAT3) supports the malignant phenotype of human pancreatic cancer. Gastroenterology 2003, I 25(3):89|-905.

18. Wei D, Le X, Zheng L, Wang L, Frey JA, Gao AC, Peng Z, Huang S, Xiong HQ, Abbruzzese JL, et al.: Stat3 activation regulates the expression of vascular endothelial growth factor and human pancreatic cancer angiogenesis and metastasis. Oncogene 2003, 22(3):319-329.

19. Greten FR, Weber CK, Greten TF, Schneider G, Wagner M, Adler G, Schmid RM: Stat3 and NF-kappaB activation prevents apoptosis in pancreatic carcinogenesis. Gastroenterology 2002 , I 23(6):2052-2063.

20. Huang C, Cao J, Huang KJ, Zhang F, Jiang T, Zhu L, Qiu ZJ: Inhibition of STAT3 activity with AG490 decreases the invasion of human pancreatic cancer cells in vitro. Cancer science 2006 , 97( I 2): |4|7-|423

21. Mora LB, Buettner R, Seigne J, Diaz J, Ahmad N, Garcia R, Bowman T, Falcone R, Fairclough R, Cantor A, et al.: Constitutive activation of Stat3 in human prostate tumors and cell lines: direct inhibition of Stat3 signaling induces apoptosis of prostate cancer cells. Cancer research 2002, 62(22):6659-6666.

22. Calvin DP, Nam S, Buettner R, Sekharam M, Torres-Roca J, Jove R: Inhibition of STAT3 activity with STAT3 antisense oligonucleotide (STAT3-ASO) enhances radiation-induced apoptosis in DUI45 prostate cancer cells. International Journal of Radiation Oncology*Biology*Physics 2003, 57(2, Supplement I):S297-S297.

23. Pham NA, Jacobberger JW, Schimmer AD, Cao P, Gronda M, Hedley DW: The dietary isothiocyanate sulforaphane targets pathways of apoptosis, cell cycle arrest, and oxidative stress in human pancreatic cancer cells and inhibits tumor growth in severe combined immunodeficient mice. Molecular cancer therapeutics 2004, 3(1 0): I239-I248.

24. Hecht SS, Kenney PM, Wang M, Upadhyaya P: Benzyl isothiocyanate: an effective inhibitor of polycyclic aromatic hydrocarbon tumorigenesis in A/J mouse lung. Cancer letters 2002 , I 87( I 2):87-94.

25. Kuroiwa $Y$, Nishikawa A, Kitamura $Y$, Kanki K, Ishii $Y$, Umemura T, Hirose $M$ : Protective effects of benzyl isothiocyanate and sulforaphane but not resveratrol against initiation of pancreatic carcinogenesis in hamsters. Cancer letters 2006, 24 I (2):275-280.

26. Sticha KR, Staretz ME, Wang M, Liang H, Kenney PM, Hecht SS: Effects of benzyl isothiocyanate and phenethyl isothiocyanate on benzo[a]pyrene metabolism and DNA adduct formation in the A/J mouse. Carcinogenesis 2000, 21 (9): $1711-1719$.

27. Fahey JW, Haristoy X, Dolan PM, Kensler TW, Scholtus I, Stephenson KK, Talalay P, Lozniewski A: Sulforaphane inhibits extracellular, intracellular, and antibiotic-resistant strains of Helicobacter pylori and prevents benzo[a]pyrene-induced stomach tumors. Proceedings of the National Academy of Sciences of the United States of America 2002, 99(I I):7610-76I5.

28. Chung FL, Conaway CC, Rao CV, Reddy BS: Chemoprevention of colonic aberrant crypt foci in Fischer rats by sulforaphane and phenethyl isothiocyanate. Carcinogenesis 2000, 2 I ( I 2):2287-229।

29. Zhang R, Loganathan S, Humphreys I, Srivastava SK: Benzyl isothiocyanate-induced DNA damage causes $\mathbf{G} 2 / \mathrm{M}$ cell cycle arrest and apoptosis in human pancreatic cancer cells. The Journal of nutrition 2006, I 36( I I):2728-2734

30. Srivastava SK, Singh SV: Cell cycle arrest, apoptosis induction and inhibition of nuclear factor kappa $B$ activation in antiproliferative activity of benzyl isothiocyanate against human pancreatic cancer cells. Carcinogenesis 2004, 25(9): I 70 I- I 709. 
31. Xu C, Shen G, Chen C, Gelinas C, Kong AN: Suppression of NFkappaB and NF-kappaB-regulated gene expression by sulforaphane and PEITC through IkappaBalpha, IKK pathway in human prostate cancer PC-3 cells. Oncogene 2005, 24(28):4486-4495.

32. Myzak MC, Hardin K, Wang R, Dashwood RH, Ho E: Sulforaphane inhibits histone deacetylase activity in BPH-I, LnCaP and PC-3 prostate epithelial cells. Carcinogenesis 2006, 27(4):8II-8I9.

33. Chaudhuri $D$, Orsulic $S$, Ashok BT: Antiproliferative activity of sulforaphane in Akt-overexpressing ovarian cancer cells. Molecular cancer therapeutics 2007, 6(I):334-345.

34. Fimognari C, Hrelia P: Sulforaphane as a promising molecule for fighting cancer. Mutation research 2007, 635(23):90-104.

35. Boulton TG, Nye SH, Robbins DJ, Ip NY, Radziejewska E, Morgenbesser SD, DePinho RA, Panayotatos N, Cobb MH, Yancopoulos GD: ERKs: a family of protein-serine/threonine kinases that are activated and tyrosine phosphorylated in response to insulin and NGF. Cell 1991, 65(4):663-675.

36. Scovassi Al, Poirier GG: Poly(ADP-ribosylation) and apoptosis. Molecular and cellular biochemistry 1999, 199(I 2): I25-I37.

37. Frank DA: STAT3 as a central mediator of neoplastic cellular transformation. Cancer letters 2007, 25 I(2):199-210.

38. Kanda $N$, Seno $H$, Konda $Y$, Marusawa $H$, Kanai M, Nakajima $T$, Kawashima T, Nanakin A, Sawabu T, Uenoyama $Y$, et al.: STAT3 is constitutively activated and supports cell survival in association with survivin expression in gastric cancer cells. Oncogene 2004, 23(28):4921-4929.

39. Okada S, Okusaka T, Ishii H, Kyogoku A, Yoshimori M, Kajimura N, Yamaguchi K, Kakizoe T: Elevated serum interleukin-6 levels in patients with pancreatic cancer. Japanese journal of clinical oncology 1998, 28(I): 12-15.

40. Chiu J], Sgagias MK, Cowan $\mathrm{KH}$ : Interleukin 6 acts as a paracrine growth factor in human mammary carcinoma cell lines. Clin Cancer Res 1996, 2(1):215-22I.

41. Yeo CJ, Abrams RA, Grochow LB, Sohn TA, Ord SE, Hruban RH, Zahurak ML, Dooley WC, Coleman J, Sauter PK, et al.: Pancreaticoduodenectomy for pancreatic adenocarcinoma: postoperative adjuvant chemoradiation improves survival. A prospective, single-institution experience. Annals of surgery 1997, 225(5):621-633. discussion 633-626.

42. Conlon KC, Klimstra DS, Brennan MF: Long-term survival after curative resection for pancreatic ductal adenocarcinoma. Clinicopathologic analysis of 5-year survivors. Annals of surgery 1996, 223(3):273-279.

43. Lillemoe KD: Current management of pancreatic carcinoma. Annals of surgery 1995, $221(2): 133-148$

Publish with Bio Med Central and every scientist can read your work free of charge

"BioMed Central will be the most significant development for disseminating the results of biomedical research in our lifetime. "

Sir Paul Nurse, Cancer Research UK

Your research papers will be:

- available free of charge to the entire biomedical community

- peer reviewed and published immediately upon acceptance

- cited in PubMed and archived on PubMed Central

- yours - you keep the copyright
BioMedcentral 